Chemical Technology Division

\title{
PRELIMINARY GEOTECHNICAL EVALUATION OF DEEP BOREHOLE FACILITIES FOR NUCLEAR WASTE DISPNSAL IN SHALES
}

\author{
Mysore S. Nataraj*
}

Date Published - January 1991

*Department of Civil Engineering, University of New Orleans.

Prepared by the

OAK RIDGE NATIONAL LABORATORY

Oak Ridge, Tennessee 37831-6285

managed by

MARTIN MARIETTA ENERGY SYSTEMS, INC., for the

U.S. DEPARTMENT OF ENERGY under Contract DE-AC05-84OR21400 
CONTENTS

\section{Page}

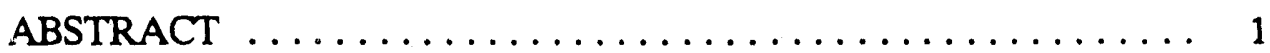

1. INTRODUCTION $\ldots \ldots \ldots \ldots \ldots \ldots \ldots \ldots \ldots \ldots \ldots \ldots$

2. GEOTECHNICAL PROPERTIES OF SHALE $\ldots \ldots \ldots \ldots \ldots, 3$

3. PRELIMINARY ASSESSMENT OF SUPPORT CAPABILITY .. 4

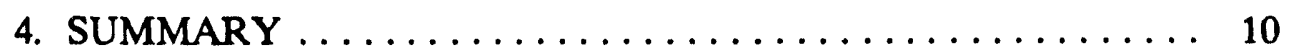

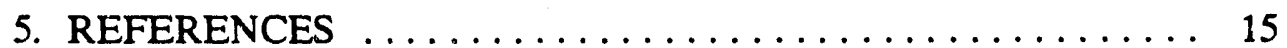

iii)iv 


\section{ACKNOWLEDGMENT}

The author expresses his sincere gratitude to Dr. T. F. Lomenick, Oak Ridge National Laboratory, for his guidance during the present study. This study was carried out under contract no. 19X-SC-206V. 


\title{
PRELIMINARY GEOTECHNICAL EVALUATION OF DEEP BOREHOLE FACILITIES FOR NUCLEAR WASTE DISPOSAL IN SHALES
}

\author{
Mysore S. Nataraj
}

\begin{abstract}
This study is concerned with a preliminary engineering evaluation of borehole facilities for nuclear waste disposal in shales. Some of the geotechnical properties of Pierre, Rhinestreet, and typical illite shale have been collected. The influence of a few geotechnical properties on strength and deformation of host material is briefly examined. It appears that Pierre shale is very unstable and requires support to prevent collapse. Typical illite shalc is more stable than Rhinestreet shale, although it undergoes relatively more deformation.
\end{abstract}

\section{INTRODUCTION}

Recently, Oak Ridge National Laboratory (ORNL) completed a comparative evaluation of five sedimentary rocks (Croff et al. 1986) - namely shale, sandstone, anhydrite, chalk, and carbonate - to determine their relative potential as host media for the disposal of radioactive wastes. It was determined that various rock-mass characteristics of shale enhance the emplacement of radioactive wastes. Characteristics of shale that are considered positive attributes for serving as a host material for waste repositories include:

(1) very low permeability; (2) high ion-exchange capacity; (3) relative plasticity, a characteristic that can promote self-healing of fractures and ensure low permeability; and (4) location (United States) at appropriate depths with large lateral and vertical extension. However, it is to be noted that shales can have a low compressive strength and may creep readily. Further, the constitutive relationship for shale at great depths has not been completely investigated, and information on the mechanical properties of shale is very limited.

The present study is concerned with deep boreholes with waste emplacement from the surface. A schematic diagram of the borehole facility is shown in Fig. 1. The basic geometry and configuration used were based on earlier studies (Croff et al. 1986, 

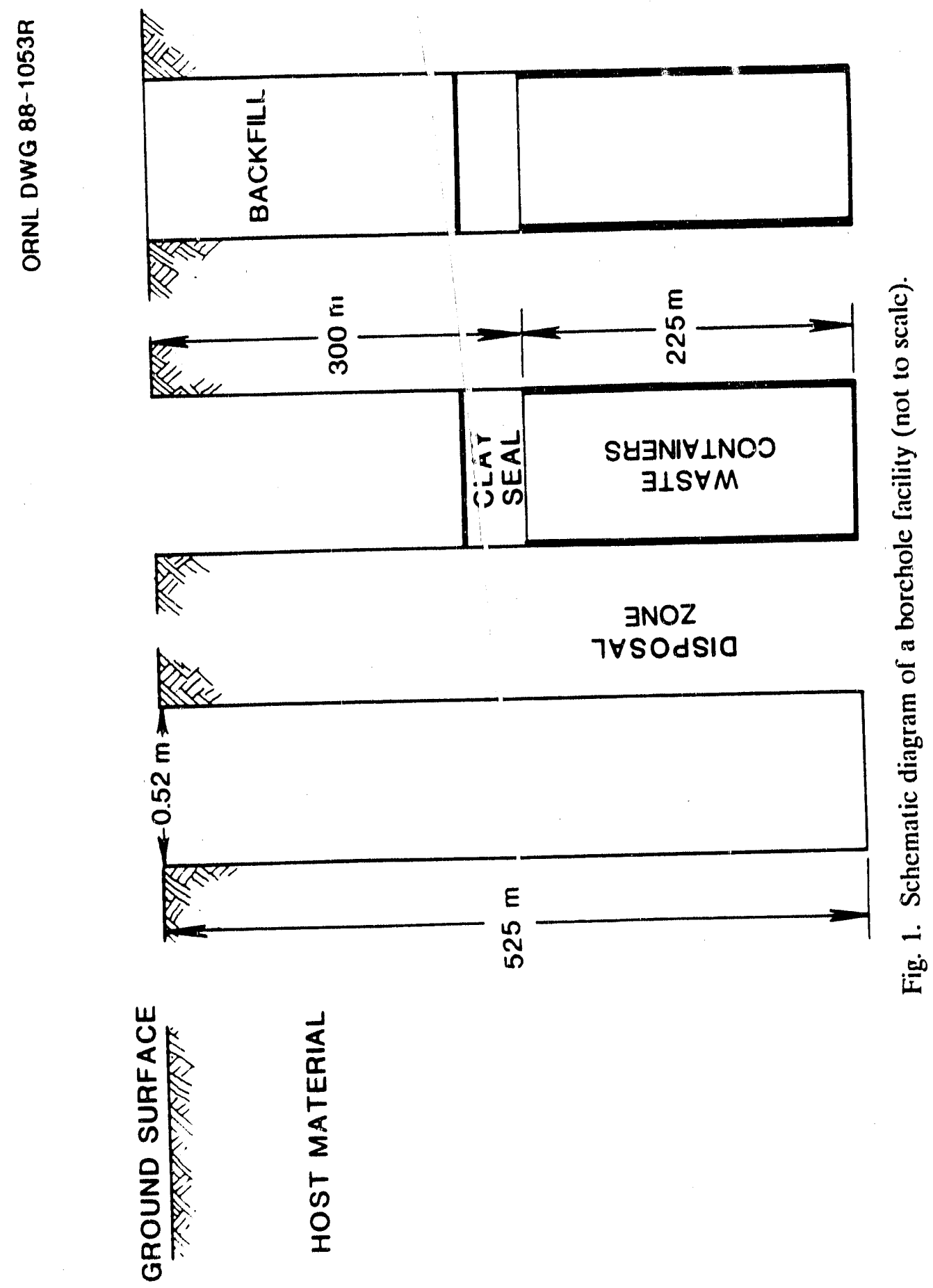
Chapman et al. 1984). The borehole is assumed to be $0.52 \mathrm{~m}$ in diameter and extend vertically to a depth of about $525 \mathrm{~m}$. The depth from the surface to the disposal zone is about $300 \mathrm{~m}$. The boreholes are laid out in a hexagonal configuration, the reference spacing being $35 \mathrm{~m}$. A deep borehole facility is a relatively inexpensive method of waste disposal. Its unique features are its complete flexibility and modular nature during operation. A limited area is used at a time, and a completed borehole site is returned to normal use fairly quickly. This is a practicable technique with sufficient support from civil and mining engineering.

\section{GEOTECHNICAL PROPERTIES OF SHALE}

A general evaluation of desirable characteristics of a host material for waste disposal includes study of hydrogeological, geochemical, mineralogical, thermomechanical, and geotechnical properties. In this study, the influence of a few geotechnical properties on strength and deformation of host material is briefly examined. The strength and stability are important characteristics because the physical integrity of the repository should not be jeopardized under any circumstances.

A host material is considered to be stable when the load-bearing capacity is sufficient to withstand external loads without inadmissible deformations. In the case of a borehole facility, this principle may have many connotations. It may mean that the borehole will have to remain open for an adequate time for deposition of waste material. The host material should be capable of supporting waste canisters over a long period. In addition, the load-bearing capacity of the host material should not be impaired as a result of sudden or gradual stress changes. Given the above considerations, the host material should not allow any deformation that may inpair the usability of the facility.

Shale is an argillaceous rock with extreme variations in its geotechnical properties, which make the evaluation of its probable behavior a difficult, although important, step in engineering considerations of a waste repository. While large amounts of information on the properties of shale have been collected, many documents and papers referenced in the literature contain only site-specific properties. The present study is confined to Pierre, Rhinestreet, and typical illite shales. The majority of properties have been collected from several reports, using original references whenever possible (Kibbe and Boch 1978, Abel 
and Gentry 1975, Kopp 1986, Hansen and Vogt 1987, Gonzales and Johnson 1985). In the selection of properties of rocks and rock mass, the inherent limitations due to the nature of the data collected, organized, and presented by various researchers need to be considered. Discussions of the scaling effect and relevance of laboratory and field tests to engineering practice are given in several publications (Goodman 1980, Bieniawski 1988, Hoek and Brown 1980).

in this study, it was necessary to assume values for some properties. These were estimated from values at a similar location, formation, or field condition. Thus, it should be emphasized that the estimated values are only approximations because of the varied nature of data available, the different test conditions and procedures, and the scaling of values. In estimating the rock-mass properties, suggestions made by various investigators (Goodman 1980, Bieniawski 1984, Kibbe and Boch 1978, Hunt 1986) have been used. A summary of the properties and their ranges used in this study for the three shales is presented in Table 1.

\section{PRELIMINARY ASSESSMENT OF SUPPORT CAPABILITY}

Rocks, in general, have adequate load-bearing capacity. However, support capability depends on rock type, nature of discontinuities and fracture, rock quality, and mineralogical composition. It is difficult to estimate the bearing capacity of rocks by taking all the factors into consideration. Also, there is no rational procedure, except conducting full-scale load tests, that can determine the allowable bearing pressure of rocks. Various procedures (empirical and theoretical) have been suggested and used by many researchers (Bowles 1988, Goodman 1980, Stagg and Zienkiewicz 1968, and Coates 1981). In this study, the approach suggested by Stagg and Zienkiewicz (1968) has been used, where the ultimate bearing capacity was reduced based on rock quality designation (RQD) as:

$$
q_{\text {reduced }}=q_{\text {ultimale }} X(R Q D)^{2} \text {. }
$$

A simple parametric study was carried out using the various values of cohesion and friction angle presented in Table 1. 
Table 1. Properties of shale

\begin{tabular}{lll}
\hline Property & Intact rock & Rock mass \\
\hline
\end{tabular}

\section{PIERRE SHALE}

Bulk density

RQD

Unconfined compressive strength

Cohesion

Friction angle

Modulus of elasticity

Poisson's ratio

Bulk density

RQD*

Unconfined compressive strength

Cohesion

Friction angle

Modulus of elasticity

Poissons's ratio
$0.02 \mathrm{~kg} / \mathrm{m}^{3}$

$28,56,84 \%$

$10,15 \mathrm{MPa}$

$0.5,1.5 \mathrm{MPa}$

$5,15,30^{\circ}$

$1000 \mathrm{MPa}$

0.2
$0.02 \mathrm{~kg} / \mathrm{m}^{3}$

6.5 $\mathrm{MPa}$

$1 \mathrm{MPa}$

$10^{\circ}$

$200 \mathrm{MPa}$

0.2

\section{RHINESTREET SHALE}

$\begin{array}{ll}0.02 \mathrm{~kg} / \mathrm{m}^{3} & 0.02 \mathrm{~kg} / \mathrm{m}^{3} \\ 28,56,84 \% & - \\ & \\ 10,25,50 \mathrm{MPa} & 25 \mathrm{MPa} \\ 5,10 \mathrm{MPa} & 10 \mathrm{MPa} \\ 5,15,30^{\circ} & 15^{\circ} \\ 17,500 \mathrm{MPa} & 3500 \mathrm{MPa} \\ 0.2 & 0.2\end{array}$

TYPICAL ILITTE SHALE

Bulk density

RQD

Unconfined compressive strength

Cohesion

Friction angle

Modulus of elasticity

Poisson's ratio

$0.02 \mathrm{~kg} / \mathrm{m}^{3}$

$28,56,84 \%$

$10,25,70 \mathrm{MPa}$

$20,30,40 \mathrm{MPa}$

$15,20,30^{\circ}$

$11,000 \mathrm{MPa}$

0.2
$0.02 \mathrm{~kg} / \mathrm{m}^{3}$

-

$30 \mathrm{MPa}$

$20 \mathrm{MPa}$

$20^{\circ}$

$2000 \mathrm{MPa}$

0.2

${ }^{\top} \mathrm{RQD}=$ rock quality designation. 
The bearing capacity ciepends on many factors, including the depth, friction angle, and cohesion. There are many suggestions for adopting an upper limit of allowable pressure on rock (Peck et al. 1974, Hunt 1986, Bowles 1988). Simplified, the maximum allowable pressure on intact rock is taken to be 1.5 times the unconfined compressive strength of samples determined in the laboratory. The maximum limit of the allowable bearing pressure is not nore than $30 \mathrm{MPa}$ for a rock with a RQD of $100 \%$. By adapting this suggestion, the curves shown in Fig. 2 were obtained from the results of parametric studies. These curves can be used in preliminary studies to estimate the allowable bearing pressure on a rock mass of specified cohesion and friction angle. However, it should be noted that the variations shown are only estimates since the curves were obtained using approximate ranges for properties. Another approximation procedure (Goodman 1980) based on considerations of unconfined compressive strength and friction angle was also used. The salient results are presented in Fig. 3, which shows the allowable bearingpressure values for various unconfined compressive strengths. The values assumed for rock mass are shown in parentheses. Since the strength of rock mass controls field behavior, it is desirable to know the allowable pressure of the rock mass. Equal allowable pressure curves are shown in Fig. 3. These curves are useful for preliminary purposes to estimate the value of allowable pressure of rock mass if friction angle and unconfined compressive strength are known. Again, it is to be noted that these curves serve only as a guide for detailed analysis.

Another way of examining borehole stability is to determine whether the artificial opening remains open or has collapsed under the existing conditions. One method (Hudson and Boden 1981) considers 'unconfined compressive strength and uses the concept of stability factor, $\mathrm{N}$. Increasing values of $\mathrm{N}$ indicate decreasing stability. Hudson and Boden (1981) also suggest a working value of $\mathrm{N}$ equal to 3 for radioactive waste repositories. However, values up to 4.5 may be quite appropriate (Chapman et al. 4 ). The stability factors for the shales under study are summarized in Table 2 . The values of the unconfined compressive strength necessary to give stability factors of 3.0 and 4.5 are shown under the "Remarks" column. In another approach (Bowles 1988), the cohesion is considered a main property and uses the concept of squeeze ratio, $R$. If $R$ is greater than 6 , squeezing takes place. If $R$ exceeds 8 , then squeezing occurs very rapidly, and the use of supporting liners or slurry is suggested. Squeeze ratios, $R$, for the three 


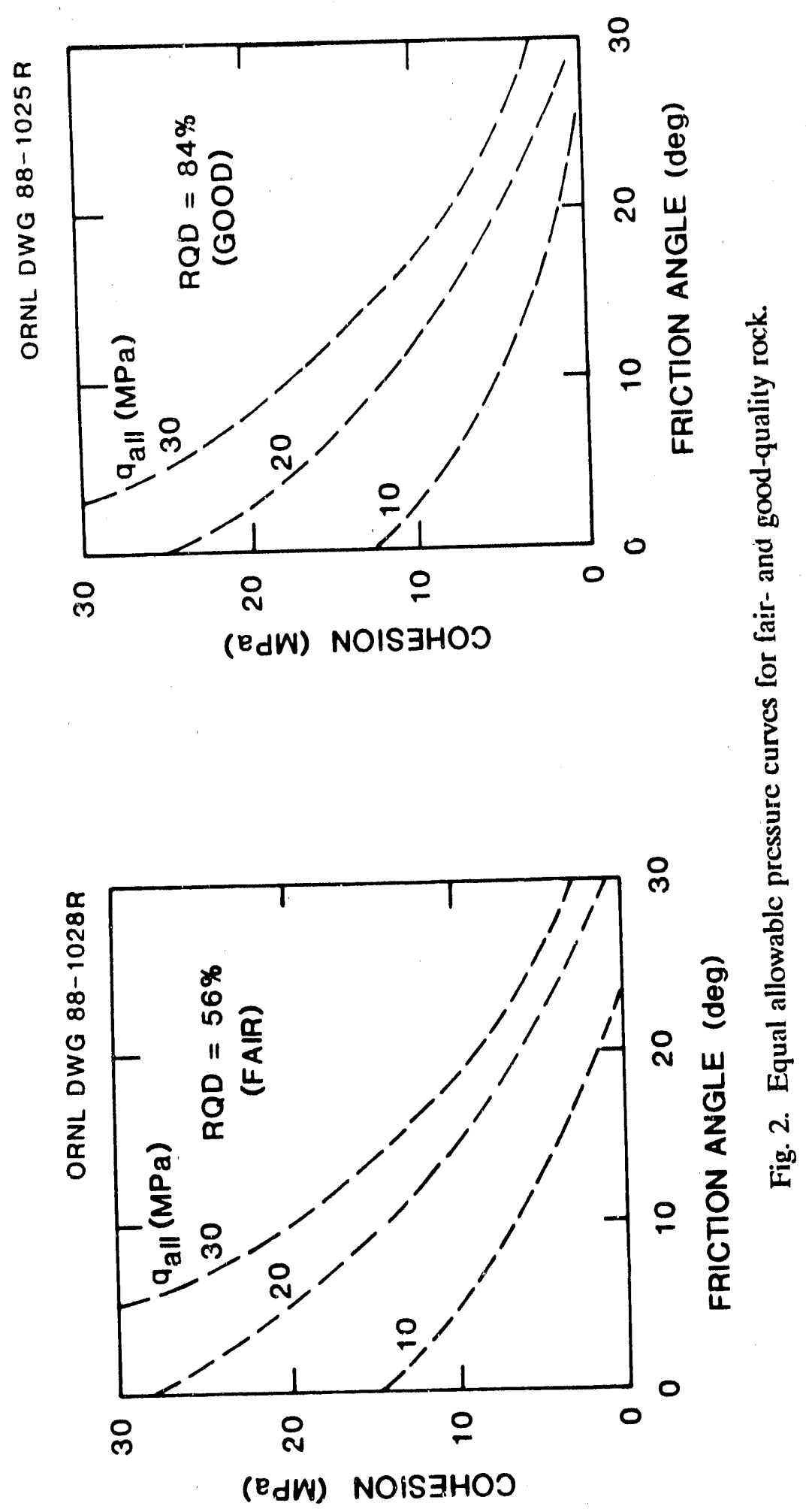




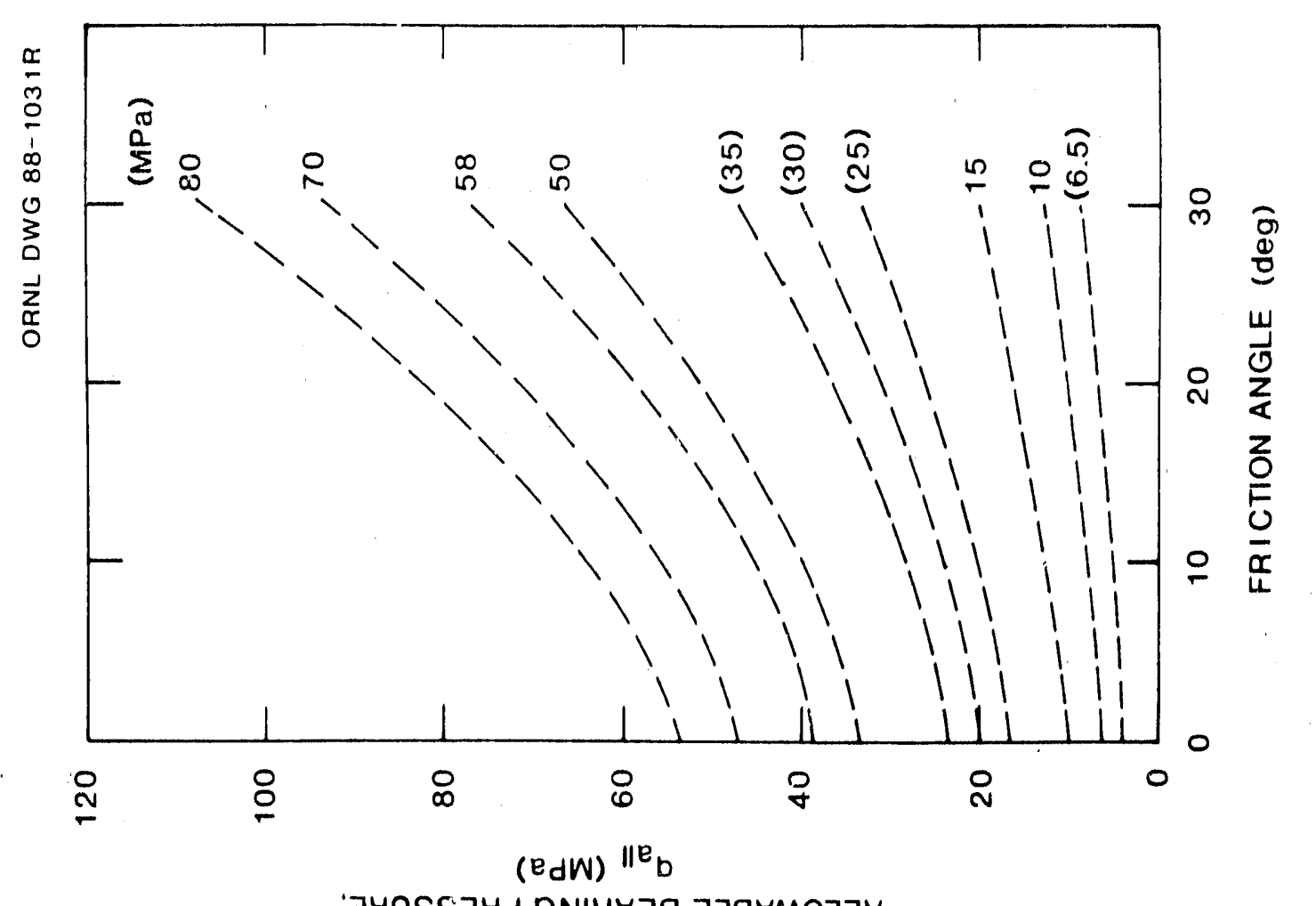

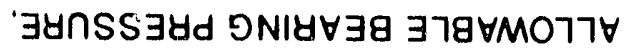

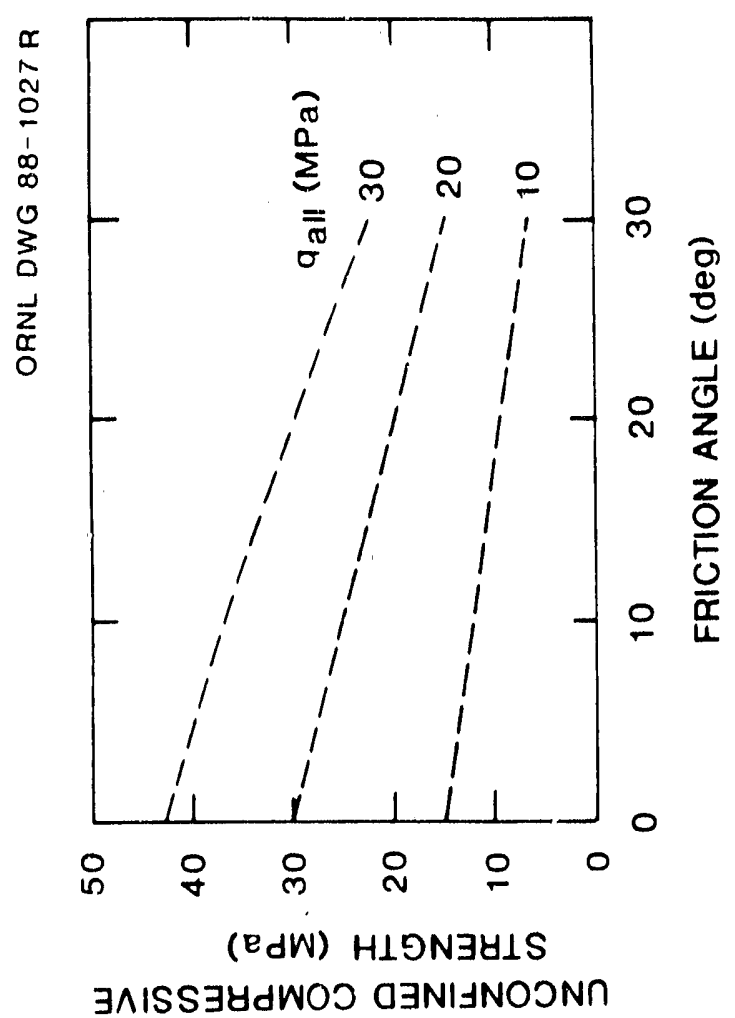


Table 2. Stability factors for shale

\begin{tabular}{llcc}
\hline $\begin{array}{l}\text { Type of } \\
\text { shale }\end{array}$ & $\begin{array}{l}\text { Stability } \\
\text { factor, } \mathrm{N}\end{array}$ & $\begin{array}{c}\text { Squeeze } \\
\text { ratio, } \mathrm{R}\end{array}$ & Remarks \\
\hline & 1.62 & 10.5 & For $\mathrm{N} \leq 3.0, \mathrm{UCS}=3.5 \mathrm{MPa}$ \\
Pierre & 0.4 & 1.05 & For $\mathrm{N} \leq 4.5, \mathrm{UCS}=2.33 \mathrm{MPa}$ \\
Rhinestreet & 0.35 & 0.53 & For $\mathrm{R} \leq 6.0, \mathrm{c}^{\mathrm{b}}=1.8 \mathrm{MPa}$ \\
Typical illite & & & \\
\end{tabular}

'UCS = unconfined compressive strength.

${ }^{b} \mathrm{c}=$ cohesion. 
shales are shown in Table 2. The values of cohesion necessary to give a squeeze ratio of less than or equal to 6 for boreholes in the present study are shown in Table 2 under the "Remarks" column. Based on the values in Table 2, the unconfined compressive strength and cohesion cé rock mass shoulo be at least 2.5 and $2.0 \mathrm{MPa}$, respectively, for adequate stability of boreholes.

An approximate assessment of the likely response of the rock mass to a set of inciuced stresses was also attempted in this preliminary study. Many methods have been frojosed and used by various researchers to obtain rock pressure curves (Goodman 1980, Bieniawski 1984, Hoek and Brown 1980, Coates 1981). Since the properties of ro $k$ mass for the shales are not described in the literature, it was necessary to make various assumpuions. In this analysis, it has been assumed, for simplicity, that the original rock mass is of good quality and the broken rock mass is of fair quality. Hence, this analysis provides only a general ides about the response of the shales. The data uscd are presinted in Table 3.

The variation of borehole deformation with support pressure for Rhinestreet and typical illite shales is shown in Fig. 4. The cfferi of modulus of elasticity is observed in typical illite shale, which und/rgoes relatively more defornation than Rhinestreet shale; however, the unconfined compressive strength of illite shale is slightly higher than that of Rhinestreat shale. Thus, the broken-znne thickness for a given support pressure is less for illite shale thait that for Rhinestreet shale, as shown in Fig. 5. In contrast, the Pierre shale, which is a very low-strength rock, appears to collapse, and large support pressure is required to reduce the deformation. This behavior of Pierre, Rhinestreet, and illite shale was previously indicated by the stability factor. In interpreting the above results, it should be noted that they are highiy sensitive to the values of various parameters such as modulus of elasticity, unconíned compressive strength, and material constants for original and broken rock mass.

\section{SUMMARY}

The primary furpose of this study was to make a pieliminary engineering evaluation of a borehole facility in shales. Some of the geotechnical properties of Pierre, Rhinestreet, and typical illite shales have been collected from the limited existing 
Table 3. Rock and rock-mass data

In situ stress

$10.5 \mathrm{MPa}$

Unit weight of broken rock

$0.02 \mathrm{~kg} / \mathrm{m}^{3}$

Material constants for original rock mass of

$\mathrm{m}=1.0$;

goo iuality

Material constants for broken rock mass of

$\mathrm{s}=0.004$

$\mathrm{m}_{\mathrm{r}}=0.2$

fair quality

Poisson's ratio for rock mass

$\mathrm{s}_{\mathrm{r}}=0.0001$

0.2

MODULUS OF ELASTICITY OF ROCK MASS

Typical illite shale

$2000 \mathrm{MPa}$

Rhinestreet shale

$3500 \mathrm{MPa}$

Pierre shale

$200 \mathrm{MPa}$

\section{UNCONFINED COMPRESSIVE STRENGTH OF INTACT ROCK}

Typical illite shale

$70 \mathrm{MPa}$

Rhinestreet shale

$50 \mathrm{MPa}$

Pierre shale

$15 \mathrm{MPa}$ 
ORNL DWG 88-1032R

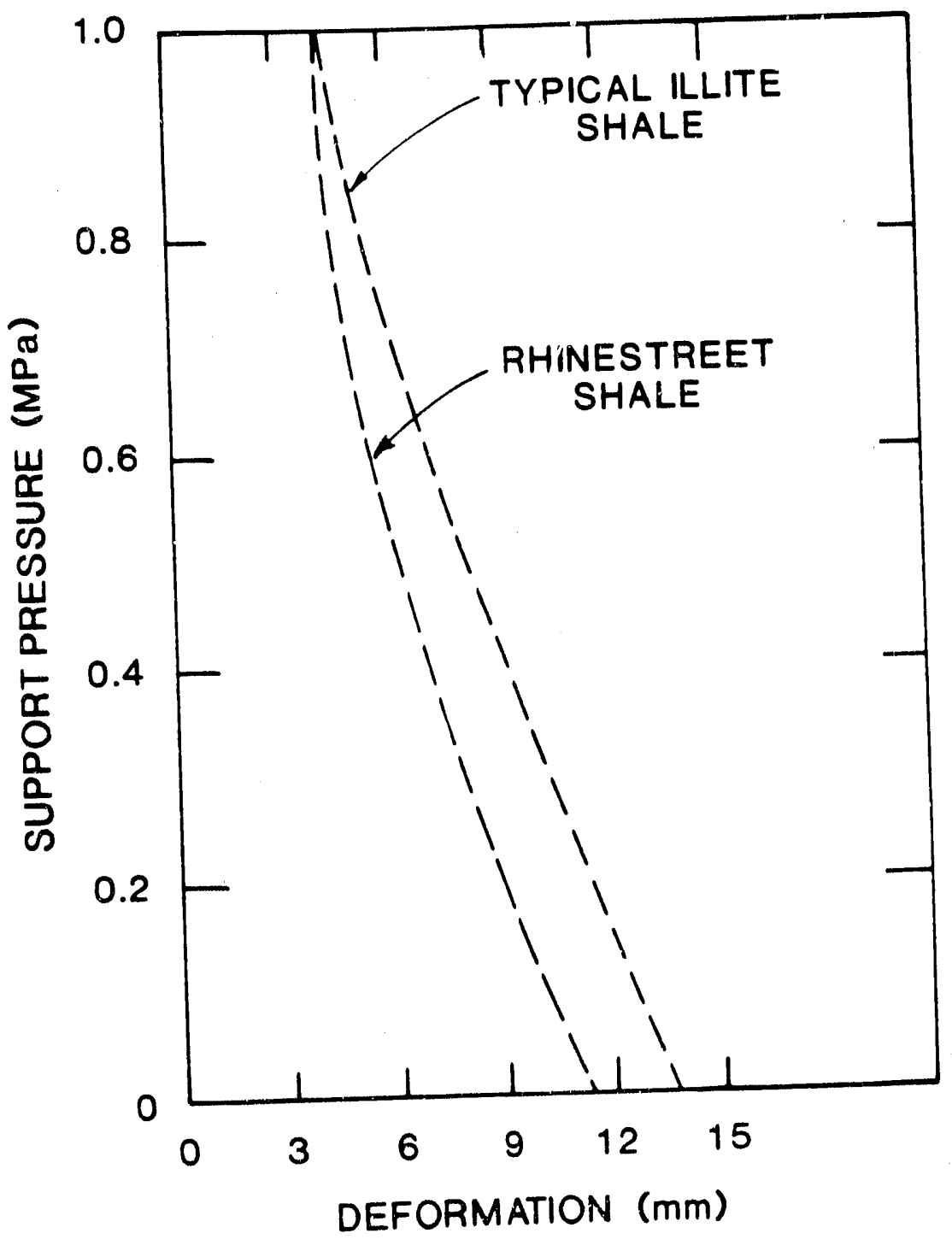

Fig. 4. Variation of borchole deformation with support pressure. 
ORNL DWG 89-10911R

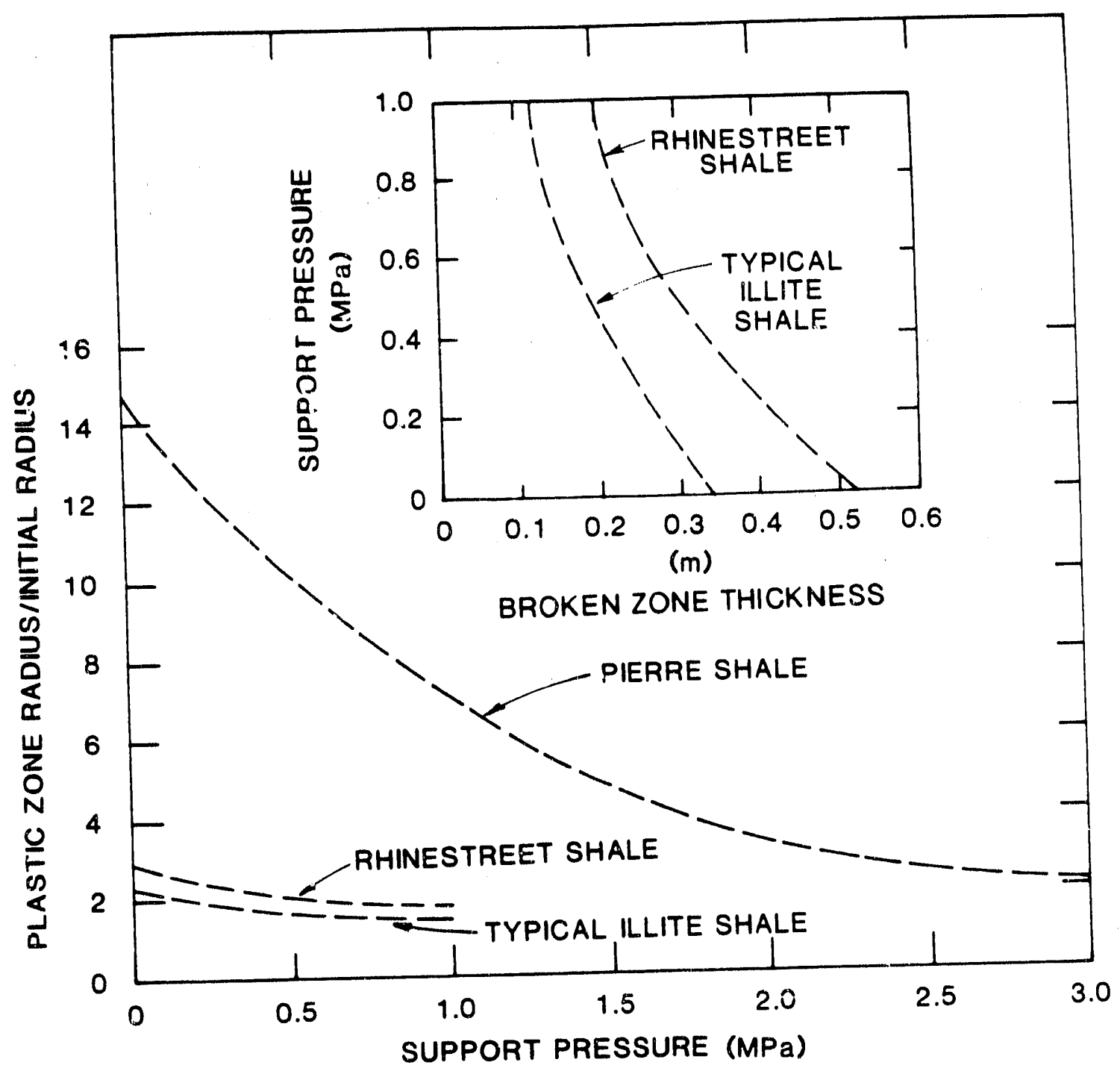

Fig. 5. Comparison of behavior of three shales. 
literature. The properties were used to estimate the bearing pressure of shales, and equal pressure curves have been developed. It appears that Pierre shale is very unstable and requires support to prevent collapse. Typical illite shale is more stable than Rhinestreet shale, although it undergoes relatively more deformation. Based on preliminary computations, the unconfined compressive strength and cohesion of rock mass are to be at least 2.5 and $2 \mathrm{MPa}$, respectively, for adequate stability of boreholes in shales. 


\section{REFERENCES}

Abel, J. F. and Gentry, D. W. 1975. Evaluation of Excavation Experience: Pierre Shale. ORNL/Sub-75/70347, Oak Ridge National Laboratory.

Bieniawski, Z. T. 1988. Rock Mechanics Design in Mining and Tunneling. A. A. Balkema Publishers, Rotterdam.

Bowles, J. E. 1988. Foundation Analysis and Design. McGraw-Hill, New York, 4th Ed.

Chapman, N. A. and Gera, F. 1984. Feasibility Study for the Disposal of High-Level Heat Emitting, Cladding Hull, and Other Wastes in the Plio-Pleistocene Blue Clays, Rome.

Coates, D. F. 1981. Rock Mechanics Principles. Monograph 874. Energy, Mines, and Resources, Canada.

Croff, A. G., Lomenick, T. F., Lowric, R. S., and Stow, S. H., 1990. Evaluation of Five Sedimentary Racks Other Than Salt for Geologic Repository Siting. ORNL-6241, Vols. 1-3, Oak Ridge National Laboratory (in preparation).

Gonzales, S. and Johnson, K. S. 1985. Shales and Otker Argillaceous Strata in the U.S. ORNL/Sub-6479:4/1, Oak Ridge National Laboratory.

Goodman, R. E. 1980. Introduction to Rock Mechanics. John Wiley and Sons, New York. Hansen, F. D. and Vogt, T. J. 1987. Themomechanical Properties of Selected Shales. RSI-0305.

Hoek, E. and Brown, E. T. 1980. Undenground Excavations in Rock. The Institution of Mining and Metallurgy, London.

Hudson, J. A. and Roden, J. B. 1981. Geotechnical c.nd Tunneling Aaspects of Radioactive Waste Disposal, Procecdings of International Tunncling Conference, United Kingdom.

Hunt, R. E. 1986. Geotechnical Engineering Analysis and Evaluation. McGraw-Hill, New York.

Kibbe, R. K. and Boch, A. L. 1978. Technical Support for GEIS: Radioactive Waste Isolation in Geologic Formations, Vol. 6. Y/OWI/TM-36/6, Oak Ridge National Laboratory. 
Kopp, O. C. 1986. A Preliminary Assessment of Mineralogical Criteria on the Utility of Argillaceous Rocks and Minerals for High-Level Radioactive Waste Disposal.

ORNL/TM-90979, Oak Ridge National Laboratory.

Peck, R. B., Hanson, W. F., and Thornburn, T. H. 1974. Foundation Engineering.

2nd Ed. John Wiley and Sons, New York.

Stagg, K. G. and Zienkiewicz, O. C. 1968. Rock Mechanics in Engineering Practice. John Wiley and Sons, New York. 

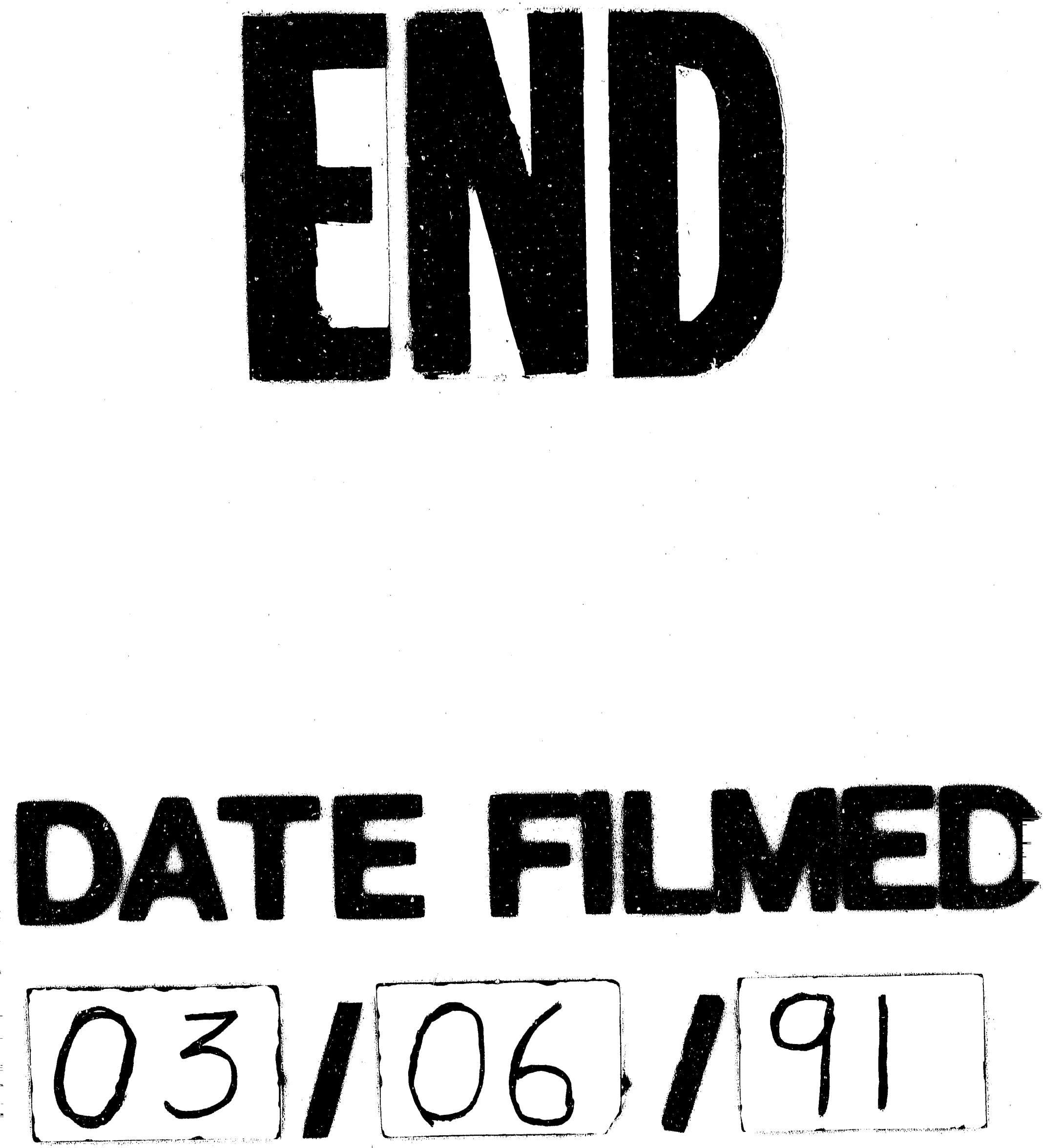
